\title{
LYSIS OF BACILLUS SUBTILIS CELLS BY BACTERIOPHAGE LYSATES (Preliminary report)
}

\author{
TAKICHI KANEKO and KAKUO KITAHARA
}

(Division of Zymomycology, the Institute of Applied Microbiology, University of Tokyo)

Received for publication, June 3, 1957

It has been previously reported by the present authors ${ }^{(1)}$ that most of the factories manufacturing bacterial amylase in Japan had been confronted with the troubles caused by the contamination of bacteriophage. In the course of studies on the phages isolated as causative agents of the troubles, some phenomena were found which were similar to, but not identical with, the classical "lysis from without(2)" and " nascent phenomena ${ }^{(3)}$ ".

Undiluted lysates, obtained by allowing the phage $\mathrm{P} 2^{(1)}$ to multiply on a sensitive bacterium, Bacillus subtilis $\mathrm{H}^{(4)}$, were capable of lysing growing cultures of the same organism practically without any time lag (Fig. 1, Curve 2).

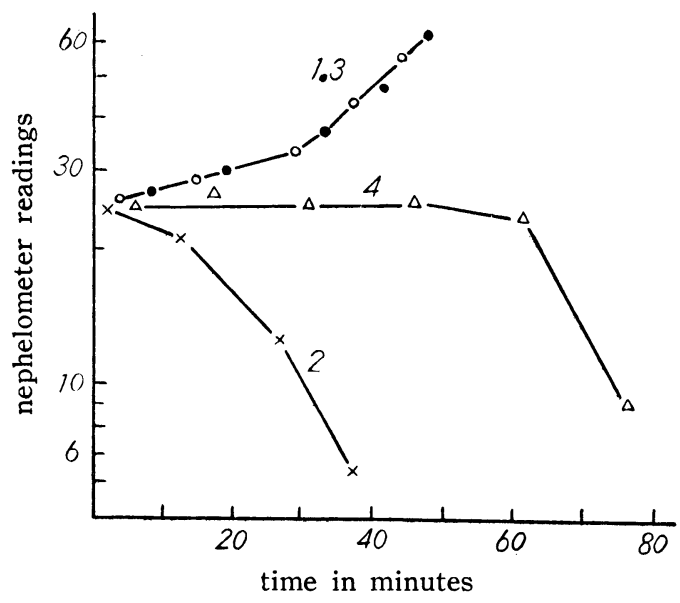

Fig. 1. Lysis of $B$. sutilis $\mathrm{H}$ by $\mathrm{P} 2$ Kysates.

Curve 1, growing cells (initial viable count, $1.6 \times 10^{9} / 10 \mathrm{ml}$ ); Curve 2, cells + untreated lysate $\left(4 \mathrm{ml} / 10 \mathrm{ml}\right.$, initial phage titer, $\left.7.2 \times 10^{10} / 10 \mathrm{ml}\right)$; Curve 3 , cells + supernatant $\left(4 \mathrm{ml} / 10 \mathrm{ml} ; 9.0 \times 10^{7} \mathrm{P} 2 / 10 \mathrm{ml}\right)$; Curve 4 , cells + sediments $\left(0.5 \mathrm{ml} / 10 \mathrm{ml} ; 8.0 \times 10^{10} \mathrm{P} 2 / 10 \mathrm{ml}\right)$. All tubes were made up to $10 \mathrm{ml}$ with nutrient broth and shaken at $30^{\circ} \mathrm{C}$. 
In order to examine whether the active agents were phage particles or not, the active lysate was centrifuged at a high speed, and the resulting supernatants and/or sediments were applied on $\mathrm{H}$ cells. The supernatant did not affect the bacterial growth (Curve 3), while the sedimented fraction killed and lysed the cells after about sixty minutes' latent period (Curve 4). A rapid lysis, however, was observed when the mixture of both fractions was used, indicating that at least two agents were involved in the lysis occurring without a lag period.

Cells of strain $\mathrm{H}$, which had been rendered incapable of supporting the viral synthesis by ultraviolet (UV) irradiation, were still lysed by the lysate. The lysis was not inhibited by ethanol, cyanide, and chloramphenicol. These facts indicate that the phenomenon is not dependent on the development of the infecting phage. (It was found that the heat-killed cells were also lysed by the same lysates. However, since they were lysed in the absence of the sedimented fraction, the lysis of the heat-killed cells seems to be caused by a different mechanism.)

Lysates resulted from $\mathrm{P} 1$ or $\mathrm{P} 3^{(1)}$-infected $\mathrm{H}$ cells could replace the sedimented fraction (but not the supernatants) of P2 lysate. In all these cases the lysis was inhibited by $\mathrm{m} / 100$ ethylene-diamine tatraacetate, which is known to prevent the earlier step(s) of the productive infections in many phage-host systems ${ }^{(5,6)}$. The active factors in the sediments were stable at $60^{\circ} \mathrm{C}$, but perfectly inactivated by heating for 10 minutes at $70^{\circ} \mathrm{C}$. They remained fully active in lysing cells even after UV-irradiation which destroyed the plaque producting activity of the phage. These facts apparently support the working hypothesis that the factor(s) concerned is the protein moiety of the phage particles.

The activity of the supernatants was also stable at $60^{\circ} \mathrm{C}$, but reduced to about one third of the initial value when treated for 10 minutes at $70^{\circ} \mathrm{C}$. The remaining activity, however, survived the treatment of 10 minutes' boiling. This appears to mean that at least two factors in the supernatant, the one heat-labile and the other heat-stable, are involved in the phenomenon.

Kinetic studies revealed that the reaction velocity was proportional to the concentration of the phage fraction and the amount of the supernatant used in the reaction mixture. It was also found that high concentrations of sucrose, polyethylene glycol, and salts inhibited the lysis, probably because of the formation of protoplasts ${ }^{(7,8)}$.

Besides the above findings an unexpected phenomenon was occasionally observed: when the cells of $B$. subtilis $\mathrm{K}(\mathrm{PK})$ were mixed with those of strain $\mathrm{H}(\mathrm{PK})^{(1)}$ and the mixture was used as an indicator, very clear plaques, typical of $\mathrm{P} 2$, were produced. Since P2 does not multiply on strain $\mathrm{K}(\mathrm{PK})^{(1)}$, this phenomenon cannot be explained except on the assumption that the cells of $\mathrm{K}(\mathrm{PK})$ strain were lysed by some unusual mechanism. In order to examine whether a similar phenomenon could occur in a liquid medium, strains $\mathrm{K}(\mathrm{PK})$ and $\mathrm{H}(\mathrm{PK})$ were cultivated together or separately and to these cultures 
a small number of $\mathrm{P} 2$ was inoculated so as to cause a mass lysis of $\mathrm{H}(\mathrm{PK})$ strain in two or three hours. The results of this experiment suggested that the cells of strain $\mathrm{K}(\mathrm{PK})$ in the mixed culture were lysed soon after the mass lysis of the $\mathrm{P} 2$-sensitive strain, $\mathrm{H}(\mathrm{PK})$. Although this phenomenon is similar to the so-called "nascence", it is not a typical one because it was shown that both supernatant and sedimented fractions were required for the occurrence of the cellular lysis of strain $\mathrm{K}(\mathrm{PK})$ as it was the case with strain $\mathrm{H}$ or $\mathrm{H}(\mathrm{PK})$.

Ralston et al. (9) reported similar observations on phage lysates of Staphylococcus aureus. This suggests that the like phenomena may occur widely in different phage-bacterium combinations.

Details of these experiments will be reported later.

The authors wish to express their thanks to Mr. Keio Aizawa of the Sericulture Experiment Station for the use of his research facilities.

\section{REFERENCES}

(1) K. Kitahara and T. Kaneko: J. Agr. Chem. Soc. Japan, in press.

(2) M. Delbrǘck: J. gen. Physiol., 23, 643 (1940).

(3) E. B. Collins: J. Dairy Sci., 35, 371 (1952).

(4) M. Nomura: J. Agr. Chem. Soc. Japan, 29, 674 (1955).

(5) P. M. Rountree: J. gen. Microbiol., 12, 275 (1955).

(6) T. Kaneko, S. Iwano, and K. Kitahara: unpublished data.

(7) C. Weibull: J. Bact., 66, 688 (1953).

(8) M. Nomura and J. Hosoda: J. Bact., 72, 573 (1956).

(9) D. J. Ralston, B. S. Baer, M. Lieberman, and A. P. Krueger: Proc. Soc. Exptl. Biol. Med., 89, 502 (1955). 